\title{
PERLINDUNGAN HUKUM BAGI KONSUMEN PADA KASUS KEAMANAN PANGAN OLEH KEJAKSAAN
}

\author{
Galih Puji Mulyono \\ Fakultas Hukum Universitas Merdeka Malang \\ J. Terusan Dieng No. 62-64; Malang; 65146; Indonesia; (0341) 580161 \\ galihpujimulyono@unmer.ac.id
}

\begin{abstract}
Food safety and safety worth consumption, intended to ensure the safety and security of consumers in the use of goods and services or produce products of business actors so that consumers can avoid physical and psychological losses. Unsafe food products that are circulated and consumed in the community are deliberately made by the perpetrators by ignoring the right of the people to consume food that is safe for their living needs and violate existing legal provisions. Law enforcement in protecting and providing food security to the community is required as a form of law not just existing and enforced to the community but can help realize the true happiness. Law enforcement, in this case, the role of the prosecutor as a public prosecutor is needed to protect consumers and the creation of legal certainty and justice. Legal regulations applicable in the case of consumer protection are not interpreted as partial by law enforcement, but comprehensively with the basis of the main purpose of legal protection for the community. The role of prosecutors in law enforcement should be more considering the adverse impact on long-term consumer health should be considered and accountable to business actors.
\end{abstract}

Keywords:Law Enforcement, Legal Protection, Role of Attorney.

\begin{abstract}
Abstrak
Keamanan dan keselamatan pangan yang layak konsumsi, dimaksudkan untuk menjamin keamanan dan keselamatan konsumen dalam penggunaan barang dan jasa atau hasil produk dari pelaku usaha sehingga konsumen dapat terhindar dari kerugian fisik maupun psikis. Produk pangan yang tidak aman yang beredar dan dikonsumsi di masyarakat memang sengaja dibuat oleh pelaku dengan mengabaikan hak masyarakat untuk mengkonsumsi pangan yang aman bagi kebutuhan hidupnya, serta melanggar ketentuan hukum yang ada. Penegakan hukum dalam melindungi dan memberikan keamanan pangan kepada masyarakat diperlukan sebagai bentuk hukum tidak sekedar ada dan diberlakukan kepada masyarakat namun dapat membantu mewujudkan kebahagian sebenarnya. Penegakan hukum dalam hal ini peran kejaksaan sebagai penuntut umum diperlukan guna melindungi konsumen dan terciptanya kepastian dan keadilan hukum.Peraturanperaturan hukum yang berlaku dalam hal perlindungan konsumen tidak dimaknai sebagai persial oleh penegak hukum, namun secara komphrehensif dengan didasarkan tujuan utama upaya pelindungan hukum bagi masyarakat. Peranan jaksa sebagai penegakan hukum harus lebih mengingat dampak buruk bagi kesehatan konsumen jangka Panjang harus dipertimbangkan dan dipertanggung jawabkan kepada pelaku usaha.
\end{abstract}

Kata kunci:Penegakan Hukum,Peranan Kejaksaan, Perlindungan Hukum. 
Ketentuan Undang-Undang Dasar Republik Indonesia Tahun 1945 Pasal 28 Huruf H Ayat 1 dan 2 dinyatakan bahwa untukmewujudkandan melindungi hak dasarseluruh warga negara Indonesia untuk memenuhi kebutuhan hidupnya, termasuk dalam hak atas pangan. Hak atas pangan dapat diterjemahkan sebagai upaya terpenuhinya kebutuhan pangan masyarakatdengan aman dan layak untuk dikonsumsi. Pangan yang dikonsumsi manusia adalah makanan maupun minuman yang merupakan kebutuhan utama bagi manusia, karena itu makanan dan minuman yang baik adalah makanan dan minuman yang memenuhi persyaratan gizi dan kesehatan.

Pangan yang dikonsumsi masyarakat Indonesia tersebut terdiri dari makanan dari tumbuhan maupun hewani. Pangan harus memenuhi beberapa prasyarat yaitu aman, bermutu, bergizi dan tersedia cukup, terutama untuk melindungi kesehatan dan keyakinan masyarakat. Gizi yang baik harus berimbang dan sesuai dengan kebutuhan. Kecukupan gizi seseorang diukur dari tingkat konsumsi kalori dan protein. Salah satu protein yang bernilai tinggi yaitu protein hewani.

Daging ayam merupakan daging yang relatif murah untuk dikonsumsi manusia untuk memenuhi protein hewani dibandingkan dengan daging-daging yang lain (daging sapi, kerbau, kambing), sehingga banyak dikonsumsi oleh masyarakat dari tingkat bawah sampai tingkat atas. Keuntungan itu dimanfaatkan pelaku usaha untuk berbuat melanggar etika berbisnis dengan menjual ayam bangkai dengan harga yang murah. Hal ini merugikan konsumen karena kandungan bakteri yang ada pada ayam bangkai ini menimbulkan efek samping yang sangat berbahaya (Oktaviani, et al., 2010).

Fakta hukum mengenai kasus keamanan yang terjadi di masyarakat terus terjadi dewasa ini karena dipengaruhi faktor motif ekonomi pelaku untuk memperoleh keuntungan yang sebesarbesarnya dan faktor dari konsumenkurang mema- hami produk yang dibeli atau dikosumsi. Kasus penjualan ayam tiren yang pernah terjadi di Indonesia disajikan pada tabel dibawah ini:

Tabel 1. Kasus Ayam Tiren

\begin{tabular}{cccl}
\hline No & Daerah & Tahun & \multicolumn{1}{c}{ Keterangan } \\
\hline 1. & Madiun & 2010 & $\begin{array}{l}\text { Ayam tiren dijual di pasar } \\
\text { tradisional } \\
\text { Ayam tiren dipasok ke } \\
\text { penjual bakso dan mie } \\
\text { ayam } \\
\text { 2. }\end{array}$ Jakung, \\
3. 2015 & Tangerang & 2016 & $\begin{array}{l}\text { Polisi menyita 1,5 ton ayam } \\
\text { tiren } \\
\text { Ayam tiren dipasok ke } \\
\text { penjual ayam panggang }\end{array}$ \\
\hline
\end{tabular}

Sumber: Data sekunder, diolah, 2010

Data kasus ayam tiren terdapat di beberapa daerah di Indonesia antara tahun 2010 sampai dengan tahun 2017. Hal tersebut tidak lain digunakan untuk menarik para konsumen untuk membeli ayam tiren. Perangkat peraturan perundangundangan yang masih belum mendukung dalam memberikan keamanan dan kelayakan kebutuhan hidup konsumen. Kenyataan konsumen Indonesia sering mengalami kasus-kasus sangat merugikan dirinya baik secara materiil maupun immateriil.

Beberapa perbuatan tertentu dan dinyatakan sebagai tindak pidana yang sangat berkaitan dengan kepentingan konsumen termuat dalam KUHPidana maupun yang terdapat diluar KUHPidana. Sedangkan, di luar KUHPidana antara lain Undang-Undang Republik Indonesia Nomor 7 Tahun 1996 tentang Pangan yang telah dicabut dengan Undang-Undang No. 18 tahun 2012 tentang Pangan, Undang-UndangRepublik Indonesia Nomor 8 tahun 1999 tentang Perlindungan Konsumen, dan Undang-Undang Republik Indonesia Nomor 36 tahun 2009 tentang Kesehatan.

Jaminan perlindungan hukum bagi masyarakat dalam hal inikonsumen oleh pemerintah agar dapat memenuhi pangan yang layak dan aman, belum sepenuhnya dijalakan secara optimal khususnya nampak dalam penanganan penegakan hukum 
dalam sistem peradilan pidana terhadap keamanan pangan masih beorientasi kepada pelaku. Penegakan hukum dalam sistem peradilan pidana dewasa ini belum berorientasi kepada perlindungan masyarakat sebagai korban secara umum.

Sistem peradilan pidana harus melindungi semua orang dan keadilan (substansial) ditujukan pada orang yang terlanggar haknya dan orang yang disangka melanggar hukum pidana harus diperlakukan secara adil (fair trial) atau keadilan prosedural (Mudzakir, 2001). Hak atas keamanan dan keselamatan tersebut dimaksudkan menjamin keamanan dan keselamatan konsumen dalam penggunaan barang dan jasa atau hasil produk dari pelaku usaha sehingga konsumen dapat terhindar dari kerugian fisik maupun psikis.

Kepentingan korban tindak pidana telah diwakili oleh alat negara yakni polisi dan jaksa, akan tetapi hubungan antara korban di satu pihak dengan polisi dan jaksa di pihak lain adalah bersifat simbolik, sementara itu hubungan antara terdakwa dengan penasehat hukum secara prinsip adalah murni dalam hubungan hukum antara pengguna jasa dan pemberi jasa yang di atur dalam hukum perdata.

Seringkali korban memiliki peranan yang sangat penting bagi terjadinya suatukejahatan, yang diharapkan dengan diperolehnya pemahaman yang luas dan mendalam tentang korban kejahatan akan dapat memudahkan dalam menemukan upaya penanggulangan kejahatan yang pada akhirnya akan bermuara pada keadilan dan menurunnya kuantitas ataupun kualitas dari kejahatan (Mansur\&Gultom, 2006).

Atas dasar sebagaimana uraian di atasmaka masalah-masalah yang terjadi landasan analisis penelitian inidifokuskanterhadap mengevaluasi dan menganalisispenegakan hukum oleh jaksa sebagai penuntut umum pada kasus keamanan pangan dalam mewujudkan perlindungan hukumbagi konsumen dan upaya jaksa dalam pelaksanaan eksekusi barang buktinya.

\section{Metode Penelitian}

Pendekatan yang digunakan ialah pendekatan empiris. Penelitian ini, hukum tidak hanya dikonsepkan sebagai keseluruhan atas asas-asas dan kaidah yang mengatur kehidupan manusia akan tetapi meliputi juga lembaga-lembaga dan proses-proses yang mewujudkan berlakunya kaidah itu dalam masyarakat, sebagaimana termanifestasi dan tersimakdalam aksi dan interaksi antar mereka(Soekanto, 2001).

Lokasi penelitian yang dipilih adalah di Kota Madiun, Adapun alasan pemilihan lokasi tersebut karena telah terjadi kasus pelaku usaha menjual ayam tiren dan sudah dilakukan penegakan hukum atas kasus yang terjadi.Jenis bahan hukum yang digunakan pada penelitian ini adalah bahan hukum Primer dan bahan hukum sekunder.

\section{Peranan Jaksa Sebagai Penuntut Umum Kasus Keamanan Pangan yang Belum Berbasis Perlindungan Hukum bagi Konsumen}

Jaksa dalam hal ini penuntut umum merupakan alat negara penegak hukum, pelindung dan pengayom masyarakat berkewajiban untuk memelihara tegaknya hukum. Lembaga Kejaksaan dengan demikian berperan sebagai penegak hukum. Penegakan hukum menurut Soerjono Soekamto (2005) adalah kegiatan menyerasikan hubungan nilai-nilai yang terjabarkan di dalam kaidah-kaidah yang mantap dan mengejawantah sikap tidak sebagai rangkaian penjabaran nilai tahap akhir, untuk menciptakan, memelihara dan mempertahankan kedamaian pergaulan hidup.

Menurut Barda Nawawi Arief (2010), kualitas penegakan hukum yang dituntut masyarakat saat ini bukan sekedar kualitas formal, tetapi terutama kualitas penegakan hukum secara materiil atau substansial seperti terungkap dalam isu sentral yang dituntut masyarakat. Berkaitan kasus keamanan pangan penegakan hukum oleh jaksa sebagai penuntut umum dapat memahami hukum 
secara materiil dalam hal ini pemilihan perbuatan hukum pidana dan bagaimana perlindungan hukum bagi korban tidak bertentangan dengan rasa keadilan, kepastian dan perlindungan Hak Asasi Manusia (HAM).

Pelaksanaan penegakan hukum pada kasus keamanan pangan yang diteliti, faktor ganti rugi paling dominan adalah faktor penegakan hukum yakni persepsi dan penilaian aparat penegak hukum terhadap kasus yang terjadi dan peraturan perundang-undangan yang dikenakan terhadap pelaku. Peraturan perundang-undang dikenakan kepada pelaku belum dikaitkan sebagai kesatuan yang utuh atara perbuatan, akibat, peraturan yang dilanggar dan perlindungan terhadap korban.

Berdasarkan kasus keamanan pangan yang diteliti kasus ayam tiren di kota Madiun, peranan dalam upaya penegakan hukum yang dilakukan jaksa di Kejaksaan Negeri Madiun sebagai penuntut umum dalam rangka memberikan perlindungan hukum untuk korban atau masyarakat dapat mengkonsumsi produk aman yang bermutu, dapat dinilai juga belum optimal, terutama jaksa sebagai penuntut umum belum melaksanakan fungsinya sebagai penuntut umum terhadap pelaku kejahatan. Penuntut umum adalah dominus litis dalam hal penuntutan. Ia bebas untuk menetapkan peraturan pidana mana yang akan didakwakan dan mana yang tidak (Hamzah, 2008).

Menurut Barda Nawawi Arief (2010) menyatakan bahwa banyak faktor yang mempengaruhi dan menentukan kualitas penegakan hukum. Faktor itu dapat berupa kualitas individual (SDM), kualitas institusional/ struktur hukum (termasuk mekanisme tata kerja dan manajemen), kualitas sarana/ prasarana, kualitas perundang-undangan (substansi hukum, dan kualitas kondisi lingkungan. Upaya penegakan hukum terkait kasus keamanan pangan di Kejaksaan Negeri Madiun di pengaruhi oleh kualitas individual, kualitas instituonal, dan kualitas perundang-undangan.
Faktor penghambat penegakan hukum kasus keamanan adalah hambatan yang dihadapi Kejaksaan Negeri Madiun pada tahun 2010 merupakan salah satu dari beberapa kejaksaan diwilayah Kejaksaan Tinggi Jawa Timur yang memiliki 2 wilayah dengan 2 Pengadilan Negeri. Wilayah hukum Kejaksaan Negeri Madiun yang luas meliputi 2 kota, yaitu kota Madiun dan Kabupaten Madiun. Banyaknya kasus yang masuk di Kejaksaan Negeri Madiun baik dari wilayah Kota Madiun dan Kabupaten Madiun menyebabkan penanganan kasus di Kejaksaan Negeri Madiun terhambat (Wibowo, 2 September 2010).

Permasalahan kurang optimalnya penangan kasus di Kejaksaan Negeri Madian dalam penegakan hukum dipengaruhi oleh beban kerja tinggi dari aparat penegak hukum. Permasalahan yang terjadi di Kejaksaan Negeri Madiun yang mempunyai 2 wilayah hukum dalam Pasal 137 KUHAP menentukan bahwa penuntut umum berwenang melakukan penuntutan terhadap siapapun yang didakwa melakukan delik dalam daerah hukumnya dengan melimpahkan perkara ke pengadilan yang berwenang mengadili.

Faktor kedua, kualitas individu (SDM) merupakan faktor penting dalam penegakan hukum bagaimana aparat penegak hukum dalam hal jaksa sebagai penuntut umum memiliki kualitas pengetahuan dan kualitas keterampilan yang menunjang dalam melaksanakan tugasnya. Namun, yang dituntut tidak hanya mempunyai kemampuan pengetahuan dan keterampilan menerapkan peraturan perundang-undangan tetapi sekaligus memiliki integritas yang tinggi sehingga menciptakan nilai kepercayaan di masyarakat yang ditegakkan dan dilindungi lewat hukum. Hukum merupakan manifestasi dari nilai kepercayaan (Nawawi, 2010).

Berdasarkan hal yang diteliti pada kasus keamanan pangan di Kejaksaan Negeri Madiun, penuntut umum belum berbasis perlindungan hukum bagi konsumen. Keamanan dan kelayakan pangan 
merupakan hak dasar masyarakat yang dijamin dan dilindungi Undang-Undang Dasar 1945. Penuntut umum kasus ayam tiren di Kota Madiun kurang memahami peraturan perundang-undangan dibidang pangan masih dilihat secara sempit hanya merujuk pada Undang-Undang Pangan semata dan belum melihat secara komprehensif dengan peraturan perundang-undangan yang terkait langsung terhadap kasus keamanan dan kelayakan pangan yang terjadi.

Berkas perkara yang disusun oleh penyidik, mencantumkan perbuatan yang dilakukan pelaku telah sesuai dengan rumusan tindak pidana UndangUndang tentang Pangan. Merujuk hasil koordinasi dengan penuntut umum Kejaksaan Negeri Madiun selama pelaksanaan penyidik oleh pihak penyidik, ternyata pihak penuntut umum menyetujui disangkakan rumusan tindak pidana UndangUndang tentang Pangan bagi perbuatan kedua orang pelaku, dan penuntut umum tidak memberikan arahan pula dapat dikenakan pasal dari Undang-Undang lain yang kemungkinan dilanggar perbuatan pelaku, karena menurut penuntut umum unsur-unsur sudah terbukti, alat bukti sudah terpenuhi dan tidak adanya korban maka penuntut umum mengenakan ketentuan UndangUndang tentang Pangan (Amin, 12 September 2010).

Betapa mutlak pentingnya fungsi surat dakwaan dalam proses penuntutan perkara pidana dilingkungan pengadian yang menjadi tugas dan tanggung jawab jaksa penuntut umum, tidak dapat mengingkari dalam rangka melaksanakan penegakan hukum dan peradilan. Penyusunan surat dakwaan oleh penuntut umum pada dasarnya sangatlah tergantung pada kesempurnaan atau kelengkapan berkas perkara hasil penyidikan. Oleh karena itu, materi petunjuk jaksa penuntut umum kepada penyidik dalam rangka kesempurnaan berkas perkara yang syarat utamanya berdasarkan Pasal 143 Ayat 2 KUHAP adalah CERMAT, JELAS dan LENGKAP (Pusat Pendidikan dan Pelatihan Kejaksaan Republik Indonesia (PPPJ), 2008).
Kasus tindak pidana penjualan ayam tiren, penuntut umum "kurang inovatif" dalam menyusun surat dakwaannya. Penuntut umum menyetujui dan sepaham dengan pasal dan undang-undang yang dipakai sebagai dasar penyidik ditahap penyidikan dengan menyusun surat dakwaan pokok (tunggal), serta tidak menyusun surat dakwaannya secara sekunder yang menghubungkan dengan Undang-Undang Perlindungan Konsumen.

Sebagaimana yang termuat dalam uraian dakwaan diatur dan diancam pidana dalam Pasal 55 Huruf b Jo. Pasal 21 Huruf d Undang-Undang Republik Indonesia Nomor 7 Tahun 1996 tentang Pangan seharusnya apa yang telah dilakukan pelaku dengan menjual ayam bangkai dengan digoreng telah dapat dinyatakan melanggar Pasal 8 Undang-Undang Republik Indonesia Nomor 8 Tahun 1999 tentang Perlindungan Konsumen. Kurang menggalinya hukum yang dilakukan jaksa sebagai penuntut umum merupakan bentuk belum optimalnya jaksa dalam upaya mewujudkan perlindungan hukum bagi konsumen. Ketentuan dalam Undang-Undang Pangan tidak mencerminkan keadilan bagi masyarakat dalam hal ini sebagai konsumen.

Ketentuan Pasal 8 Undang-Undang Perlindungan Konsumenadalah ketentuan umum yang diberlakukan secara general bagi pelaku usaha dari para pelaku usaha di negara Republik Indonesia. Secara garis besar menurut Gunawan Widjaja \& Ahmad Yani (2000) larangan yang dikenakan dalam Pasal 8 Undang-Undang Perlindungan Konsumen tersebut dapat dibagi dalam dua bentuk pokok, yaitu larangan mengenai produk itu sendiri, yang tidak memenuhi syarat dan standar yang layak untuk dipergunakan atau dipakai oleh konsumen, dan larangan mengenai ketersediaan informasi yang tidak benar, tidak akurat dan yang menyesatkan konsumen.

Ketentuan Pasal 8 Ayat 1 Huruf a UndangUndang Perlindungan Konsumen menjelaskan 
bahwa pelaku usaha dilarang memproduksi barang yang tidak memenuhi atau tidak sesuai dengan standar yang dipersyaratkan oleh undang-undang. Terkait dengan Undang-Undang tentang Pangan, maka telah dinyatakan pangan yang tercemar tidak boleh diedarkan oleh pelaku usaha. Bahwa pelaku usaha perseorangan tidak hanya yang berbadan hukum, apabila melakukan usaha memproduksi barang semestinya tunduk pada ketentuan Pasal 8 Ayat 1 Huruf a Undang-Undang Perlindungan Konsumen.

Penuntut umum hanya menuntut pidana penjara 1 tahun 2 bulan penjara lebih ringan dari ketentuan pokok dalam Pasal 55 Undang-Undang Pangan yakni maksimal 5 tahun penjara. Dasar pertimbangan penuntut umum adalah pelaku menyesali perbuatanya dan tidak akan mengulangi menjual ayam bangkai/ayam tiren, pelaku sudah usia lanjut, dan para pelaku melakukan kebutuhan tersebut untuk menafkahi keluarganya (Amin, 12 September 2010).

Penuntut umum selayaknya mempertimbangkan perlindungan hukum bagi konsumen atau masyarakat sebagai korban, serta aspek penjeraan bagi pelaku dan pencegahan bagi calon pelaku lainnya secara seimbang untuk melakukan penuntutan maksimal sesuai dengan ancaman pidana dalam undang-undang pangan tersebut. Pertimbangan perlindungan hukum bagi konsumen perlu mendapatkan perhatian serius dari pihak penuntut umum dalam melakukan penuntutan, karena tingkat bahaya dari segi kesehatan yang ditimbukan oleh ayam bangkai/ayam tiren yang jelasjelas sudah merupakan bangkai dan tidak layak konsumsi.

Tindakan jaksa sebagai penuntut umum menuntut pelaku kejahatan dengan ketentuan pidana adalah untuk kepentingan perlindungan hukum terhadap masyarakat dan juga kepentingan korban (Teguh \& Abdul, 2012). Kesalahan penuntut umum dalam memahami substansi peraturan perundangundangan berdampak pada putusan hakim di per- sidangan. Sehingga hal tersebut hanya melaksanakan tugas dan wewenangnya semata, institusi hukum berlangsung "kaku dan formal" sesuai dengan prosedur hukum menegakkan hukum sebatas" beyound the call of duties", belum termotivasi melaksanakan kewajiban hukum yang diembannya. Praktek hukum hanya mengikuti cara" menegakan hukum menurut bunyi teks (black letter law) (Raharjo, 2008).

Surat tuntutan mengandung penegakan kepastian hukum harus bermuara dalam rasa keadilan yang hidup dalam masyarakat sehingga penegakan hukum bukan sekedar menerapkan ketentuan hukum yang abstrak terhadap keadaankeadaan yang konkrit dan harus berisi pengkajian serta penghalusan terhadap peraturan-peraturan yang berlaku dalam berbagai kaitanya yang relevan satu dengan yang lainnya, situasi dan kondisi yang meliputi tindak pidana itu sendiri beserta lingkungannya tempat dan waktu terjadinya faktor-faktor subyektif dari terdakwa, kepentingan masyarakat yang dilanggar dan sebagainya.

Dengan demikian, maka putusan hakim akan dapat menciptakan kesinambungan secara proposional antara kepentingan masyarakat disatu pihak dan pelaku dilain pihak sebagai individu yang dijatuhi hukuman. Kerangka inilah asas-asas dan tujuan pokok dari pada penegakan hukum pidana, maka oleh karena itu walaupun jaksa penuntut umum bertindak sebagai pihak yang memegang perkara seakan-akan hanya melihat dari pertimbangan subyektif, namun jaksa penuntut umum dengan mengajukan perkara tersebut kepengadilan harus tetap berpegang teguh kepada tujuan subyektif dari penegakan hukum yaitu mewujudkan keadilan yang proposional berdasarkan kebenaran materiil.

Kebenaran materiil berkaitan kualitas substansi dari perundang-perundangan di bidang pangan dalam hal ini Pasal 62 Undang-Undang Perlindungan Konsumen, terdapat beberapa ketentuan yang di dalamnya belum berbasis perlindung- 
an hukum bagi konsumen. Hal ini juga faktor mempengaruhi belum optimalnya penuntut umum dalam mewujudkan perlindungan hukum bagi konsumen karena ada permasalahan yuridis dalam peraturan perundangan-undangan tersebut.

Permasalahan yuridis tersebut terdapat dalam ketentuan pidana dalam Pasal 62UndangUndang Perlindungan Konsumen yang belum mencerminkan perlindungan hukum bagi konsumen antara lain, menurut Barda Nawawi Arief (2010), Eksistensi ketentuan pidanaPasal 62 UndangUndang Perlindungan Konsumen menyebutkan subyek hukum pidana ada 2 yaitu pelaku usaha perorangan dan badan hukum. Namun, dalam ketentuan tersebut tidak membedakan antara besaran pidana dan denda yang dijatuhkan terhadap pelaku usaha perorangan atau badan hukum. Pidana dan denda yang dijatuhkan kepada subyek hukum harus dibedakan karena dampak yang timbulnya korban dari perbuatan badan hukum lebih besar dari pada perbuatan perorangan(Arief, 2010), sehingga ketentuan mengenai badan hukum tidak mencerminkan asas keadilan dan kepastian hukum untuk memberikan perlindungan hukum bagi konsumen.

Eksistensi dan posisi hukum korban tindak pidana dalam sistem peradilan pidana, tidak menguntungkan bagi korban tindak pidana, karena terbentur dalam permasalahan yang mendasar yakni korban hanya sebagai saksi (pelapor atau korban). Menurut Barda Nawawi Arief (2010), sistem perumusan pidana dalam Pasal 62 Undang-Undang Perlindungan Konsumen lebih berorientasi pada "pelaku tindak pidana" (offenders oriented), sebenarnya tidak dapat diharapkan banyak adanya perlindungan terhadap konsumen sebagai "korban".

Dengan dipidananya pelaku pelaku berdasarkan Pasal 62 Undang-Undang Perlindungan Konsumen saja (pidana penjara atau denda), korban/ konsumen yang dirugikan tidak mendapatkan apaapa. Dilihat dari sudut konsumen, harapan adanya bentuk perlindungan secara langsung hanya pada bentuk sanksi "pembayaran ganti rugi". Namun dalam Pasal 63 Undang-Undang Perlindungan Konsumen menjelaskan bahwa hanya merupakan "pidana tambahan".

Kedudukan sanksi "pembayaran ganti rugi sebagai pidana tambahan dalam Pasal 63UndangUndang Perlindungan Konsumen,menurut Barda NawawiArief (2010), merupakan suatu kemajuan dibandingkan dalam KUHP. Dengan adanya pidana ganti rugi mewujudkan adanya kebijakan berorientasi pada korban (victim oriented).

Namun perlu dicatat, bahwa KUHP adalah aturan umum. Aturan delik/khusus, seperti UndangUndang Perlindungan Konsumen ini sebenarnya bisa saja kebijakan perumusan sanksi yang berorientasi pada korban, dilakukan dengan cara pidana pembayaran ganti rugi sebagai pidana pokok atau sebagai pidana tambahan yang bersifat imperatif untuk delik-delik/kondisi-kondisi tertentu. Menempatkan pidana ganti rugi sebagai pidana tambahan yang bersifat fakultatif, dirasakan kurang mengakomodasikan "ide" yang tertuang dalam Pasal 4 Sub h Undang-Undang Perlindungan Konsumen dan Pasal 19 Ayat 1 UndangUndang Perlindungan Konsumen.

Apabila sanksi pidana denda yang dijatuhkan atas perbuatan pelaku usaha badan hukum hanya dipandang ringan sebagai biaya rutin sebagaimana biaya rutin yang dibutuhkan dalam biaya produksi perusahan. Berkaitan dengan ini lebih jelas Susanto (1995) bahwa, melihat praktek penegakan hukum terhadap pelanggaran-pelanggaran yang dilakukan korporasi, agaknya bagi korporasi, pelanggaran hukum yang dilakukan hanya dipandang sebagai "ongkos", yakni biaya atau pengurangan keuntungan "melalui denda" yang dikalkuasikan dan diperhitungkan sebelumnya dengan cara seperti halnya dengan setiap "ongkos" yang harus dikeluarkan untuk menghasilkan dan memasarkan produk dari korporasi yang bersangkutan.

Peraturan perundang-undangan yang baru yang mengatur perlindungan hukum bagi kon- 
sumen terkait dengan keamanan dan kelayakan pangan di atur dalam Undang-Undang Republik Indonesia Nomor 18 tahun 2012 Perubahan atas Undang-Undang Republik Indonesia Nomor 7 Tahun 1996 tentang Pangan. Pasal 90 Undang Undang tentang Pangan mengatur perbuatan dilarang bagi setiap orang mengedarkan pangan tercemar. Ketentuan lebih lanjut mengenai sanksi bagi pelanggar dikenakan sanksi administratif ini merupakan kemajuan dalam hal perlindungan bagi korban dimana korban mendapatkan perhatian khusus untuk mendapatkan ganti kerugian dan sanksi ini menghapus sanksi pidana yang sebelumnya di atur dalam undang-undang sebelumnya.

Selain dalam hukum materiil dalam hukum formiil KUHAP, juga hanya mefokuskan pada kepentingan pelaku tidak ada perlakuan lebih terhadap korban kejahatan. Sistem peradilan pidana sekarang ini berlaku terlalu difokuskan pada pelaku dan kurang memperhatikan korban. Hal yang sering terjadi adalah terlibatnya korban dalam sistem peradilan pidana hanya menambah trauma dan meningkatkan rasa ketidak berdayaannya serta frustasi karena tidak diberikan perlindungan dan upaya hukum yang cukup.

Sistem peradilan pidana dewasa ini memang terlalu "offender centered", sehingga mengharuskan kita untuk memperbaiki posisi korban dalam sistem ini agar apa yang diperolehnya tidak hanya kepuasan simbolik (Reksodiputro, 1994). Asas-asas hukum acara pidana yang dianut oleh KUHAP pun hampir semua mengedepankan hak-hak tersangka. Paling tidak terdapat sepuluh asas yang dianut oleh KUHAP dengan maksud untuk melindungi hak warga negara dalam proses hukum yang adil (Atmasasmita, 1996).

Uraian di atas menunjukan bahwa masalah kepentingan korban tindak pidana masih saja mendapat tantangan dari sudut mekanisme peradilan pidana. Selama ini pengaturan perlindungan korban khususnya dalam sistem peradilan pidana Indonesia belum menampakkan pola yang jelas.
Menurut Muladi dan Barda NawawiArief (1992), dalam hukum pidana positif yang berlaku pada saat ini perlindungan korban lebih banyak merupakan "perlindungan abstrak" atau "perlindungan tidak langsung".

Hal di atas, dapat dicermati bahwa berbagai rumusan tindak pidana dalam peraturan perundangundangan selama ini pada hakekatnya telah ada perlindungan in abstracto secara langsung terhadap kepentingan hukum dan hak asasi korban. Dikatakan demikian, karena tindak pidana menurut hukum positif tidak dilihat sebagai perbuatan menyerang atau melanggar kepentingan hukum seseorang (korban) secara pribadi dan konkret, tetapi hanya dilihat sebagai pelanggaran "norma atau tertib hukum in abstracto".

Sebagai akibatnya perlindungan korban tidak secara langsung dengan in concreto, tetapi hanya in abstracto. Ketiadaan hak korban ikut campur dalam sistem peradilan pidana, proses peradilan menjadi monopoli aparat hukum. Hal ini jelas nampak dalam menempatkan korban hanya sebagai saksi tanpa memberikan hak perlindungan hukum bagi konsumen.

\section{Upaya Jaksa dalam Pelaksanaan Eksekusi Terhadap Barang Bukti}

Mengenai perusakan atau pemusnahan barang sitaan yang membahayakan lingkungan dan masyarakat dapat dinyatakan sah, apabila berdasarkan putusan pengadilan. Perintah pemusnahan atau perusakan itu harus mendapatkan izin dari ketua pengadilan negeri, sehingga dengan demikian ada jaminan yang mengikat bagi pengadilan untuk menjatuhkan senada dengan pemusnahan benda sitaan (PPPJ, 2008).

Pemusnahan benda sitaan barang berupa (Polresta Madiun, 2010):

a. 105 ekor daging ayam yang sudah mati;

b. 27 ekor daging ayam goreng sudah mati;

c. 24 ekor daging ayam yang sudah mati; 
d. 2 buah baki; dan

e. 4 buah tas anyaman plastik.

Kewenangan dan tanggung jawab yuridis atas benda sitaan pada instansi penyidikan sejak saat benda itu disita dan ditempatkan di Rubasan. Sejak penyidikan menyita suatu suatu benda dalam pemeriksaan penyidikan, kemudian penyampaian benda sitaan dalam Rupbasan, sejak itu kewenangan dan tanggung jawab yuridis aparat penyidik atas benda sitaan, selama pemeriksaan perkara masih dalam tingkat penyidikan kewenangan dan tanggung jawab sepenuhnya atas benda sitaan mutlak berada ditangan aparat penyidik, instansi penuntut umum atau pengadilan tidak dapat mencampuri kewenangan dan tanggung jawab tersebut.

Kewenangan dan tanggung jawab yuridis aparat penyidikan atas benda sitaan secara yuridis ada di tangan aparat penyidik, lazim disebut dengan "benda sitaan penyidik". Ini berarti, selama benda sitaan berada dalam status penyidikan, penyidik berwenang dan bertanggung jawab melakukan tindakan sebagaimana dengan yang diatur dalam Pasal 45 dan 46 KUHAP.

Mengenai kewenangan penyidik atas benda sitaan yang disebut pada Pasal 45 KUHAP didasarkan atas keadaan benda sitaan, yakni merupakan:

1. Benda yang mudah rusak;

2. Benda yang membahayakan; dan

3. Biaya penyimpanan benda tersebut terlampau tinggi maka penyidik dalam tingkat pemeriksaan penyidik mempunyai wewenang untuk:

a. Menjual lelang benda sitaan, atau

b. Mengamankan benda sitaan

Penuntut umum hendak memusnahkan benda sitaan karena dianggap berbahaya bagi kesehatan manusia dan lingkungan, tindakan yang harus dilakukan dulu mendapatkan izin dari ketua pengadilan negeri jika pemusnahan atau pengamanan itu dilakukan pada tingkat penuntutan, dan izin persetujuan dari dari hakim yang mengadili perkara dalam tindakan itu dilakukan di tingkat pengadilan.Tindakan pemusnahan benda sitaan ini penuntut umum hanya terbatas pada tingkat penuntutan saja. Tetapi meliputi tingkat pemeriksaan pengadilan dalam semua tingkat.

Pengadilan pada tahap penjatuhan putusan disetiap tingkat instansi dapat menjatuhkan putusan yang memerintahkan pemusnahan benda sitaan. Kewenangan tersebut ditentukan dalam Pasal 46 Ayat 2 KUHAP, dan kewenangan ini hanya memberikan undang-undang kepada instansi pengadilan pada setiap tingkat pemeriksaan. Kewenangan ini mutlak monopoli instansi penyidik pada tingkat pemeriksaan penyidikan maupun kepada instansi penuntut umum pada tingkat penuntutan. Jadi selama benda sitaan mengikuti tingkat pemeriksaan pengadilan, pengadilan yang berwenang menetapkan kepada siapa benda sitaan dimusnahkan. Pengadilan berwenang untuk menjalankan putusan yang memerintahkan untuk memusnahkan benda sitaan.

Pelaksanaan penanganan barang bukti kasus tindak pidana penjualan ayam bangkai atau ayam tiren, barang bukti disita oleh penyidik dengan disaksikan oleh tersangka, keluarga tersangka dan ketua RT (Rukun Tetangga), hal tersebut telah mendapatkan persetujuan dari ketua Pengadilan Negeri Kota Madiun (Amin, 23 Oktober 2010).

Namun dalam pelaksanaan eksekusi terhadap barang bukti yang di laksanakan eksekusi pemusnahan barang bukti di tingkat penyidik tidak disertai dengan surat keterangan dari hasil sample tersebut, seharusnya dilakukan pemeriksaan laboratorium terlebih dahulu untuk membuktikan suatu substansi membahayakan kesehatan dapat dilakukan oleh labratorium kesehatan untuk mendapatkan kepastian keabsahan dalam pembuktian di persidangan.Kekurangan penyidik dalam pemeriksaan tersangka terkait barang bukti seharusnya penyidik dalam analisis atau penilaian ter- 
hadap barang bukti terdapat ayam bangkai/ayam tiren dalam bentuk ayam yang digoreng itu merupakan modus operandi tersangka untuk mengelabuhi konsumen (Polresta Madiun, 2010).

Kekurangan alat bukti keterangan ahli atau surat berupa hasil sampel dari laboratorium yang menerangkan kandungan bakteri yang terdapat dalam ayam tiren. Penyidik hanya melampirkan berita acara pemusnahan barang sitaan disertai dengan foto tanpa disertai surat hasil sampel dari laboratorium karena menurut keyakinan dari jaksa dan keterangan ahli maka barang bukti tersebut tidak perlu dimintakan hasil sample dari laboratorium (Nur Amin, 12 September 2010).

Surat hasil sample dari laboratorium nantinya dapat digunakan dalam pembuktian di persidangan dan memperkuat unsur kesalahan terdakwa serta bahan pertimbangan hakim dalam menjatuhkan putusan pidananya lebih berat, karena ada pembuktian akibat yang berbahaya dari penjualan ayam Bangka atau ayam tiren oleh tersangka bagi masyarakat. Kurang telitinya penuntut umum dalam melaksanakan tugasnya dengan tidak melampirkan surat hasil sampel dari laboratorium tersebut bisa dimanfaatkan karena kurangnya bukti mengenai bahayanya ayam tiren tersebut bagi kesehatan.

\section{Simpulan}

Penegakan hukum oleh jaksa sebagai penuntut umum pada kasus keamanan pangan belum optimal dalam upaya perlindungan hukum bagi konsumen. Belum optimalnya penegakan hukum oleh penuntut umum di pengaruhi bebarapa faktor antara lain beban kerja penuntut umum di Kejaksaan Negeri Madiun pada tahun 2010 yang tinggi karena memiliki 2 wilayah hukum yaitu Kota Madiun dan Kabupaten Madiun. Selain itu faktor lainnya adalah penuntut umum kurang memahami peraturan perundang-undang mengenai keamanan pangan hanya menggunakan undang-undang pangan yang memiliki sanksi ringan dan kurang memperhatikan perlidungan terhadap konsumen. Ketentuan dalam Undang-Undang Perlindungan Konsumen dirasa lebih tepat digunakan oleh penuntut umum karena selain sanksinya lebih berat ada perhatian khusus perlindungan hukum bagi konsumen.

Upaya kejaksaan dalam pelaksanaan eksekusi barang bukti kasus tindak pidana penjualan ayam bangkai/ayam tiren terdapat kekurangan, yakni dalam berkas perkara dari penyidik tidak di lengkapi dengan hasil sample dari laboratorium menerangkan bahwa barang bukti ayam bangkai memang berbahaya untuk dikonsumsi.

\section{Saran}

Kejaksaan Negeri Madiun yang terkait dengan persoalan keamanan pangan hendaknya dapat lebih mendalami persoalan tersebut dengan mendalami ketentuan undang-undang berkaitan keamanan pangan dan lebih menekankan perlindungan hukum bagi konsumen sebagai korban.

\section{DAFTAR PUSTAKA}

Amin, Nur. Kasubsi Penyidikan/ Jaksa Penuntut Umum. Kejaksaan Negeri Kota Madiun. Wawancara. 23 Oktober 2010. Madiun.

Arief, Barda Nawawi. 2010. Masalah Penegakan Hukum dan Kebijakan Hukum Pidana dalam Penanggulangan Kejahatan. Kencana Prenada Media Group. Jakarta.

Arief, Dikdik M Mansur \& Elisatris Gultom, 2006. Urgensi Perlindungan Korban Kejahatan: Antara Norma dan Realita. Rajawali Pres. Jakarta.

Atmasasmita, Romli. 1996. Sistem Peradilan Pidana (Persepektif Ekistensialisme dan Abolisionisme). Bina Cipta. Bandung.

Hamzah, Andi. 2008. Hukum Acara Pidana Indonesia. Sinar Grafika. Jakarta. 
Kepolisian Resort Kota Madiun, Berkas Acara No.BP/05/ 01/2010/Satreskrim tentang Perkara Tindak Pidana Mengedarkan Pangan yang Dilarang untuk Diedarkan (Bangkai daging Ayam), 29 Januari 2010, Madiun.

Kitab Undang-Undang Hukum Acara Pidana.

Mudzakir. 2001. Posisi Hukum Korban Tindak Pidana dalam Sistem Peradilan Pidana. Disertasi Pengukuhan Guru Besar di Universitas Indonesia. tanggal 6 April 2001. Jakarta.

Muladi \& Barda Nawawi Arief. 1992. Bunga Rampai Hukum Pidana. Alumni. Bandung.

Oktaviani, Wina dkk. 2010. Perlindungan Konsumen (online), www.w3.org/1999/xhtml., (diakses tanggal diakses 26 Juli 2010).

Prasetyo, Teguh \& Abdul Halim Barkatullah. 2012. Politik Hukum Pidana, "Kajian Kebijakan Kriminalisasi dan Dekriminilisasi". Pustaka Pelajar. Yogyakarta.

Pusat Pendidikan dan Pelatihan Kejaksaan Republik Indonesia. 2008. Modul Pendidikan dan Pelatihan Pembentukan Jaksa (PPPJ-2008). Kejaksaan Republik Indonesia. Jakarta.

Raharjo, Satjipto. 2008. Memunculkan Kekuatan Hukum. bahan bacaan mahasiswa PDIH-UNDIP N0. 27. PDIH-UNDIP. Semarang.

Reksodiputro, Mardjono. 1994. Hak Asasi Manusia dalam Sistem Peradilan Pidana. Pusat Pelayanan Keadilan dan Pengabdian Hukum Universitas Indonesia. Jakarta.
Soekanto, Soerjono, 2001. Pengantar Penelitian Hukum. Cet V. UI-Press. Jakarta.

Soekanto, Soerjono. 2005. Faktor-Faktor yang Mempengaruhi Penegakan Hukum. Raja Grafindo Persada. Jakarta.

Susanto, I.S. 1995. Kejahatan Korporasi, Badan Penerbit Universitas Diponegoro. Semarang.

Sutarto, Suryono. 2004. Hukum Acara Pidana Jilid I. Universitas Diponegoro. Semarang.

Undang-Undang Dasar Republik Indonesia Tahun 1945.

Undang-Undang Republik Indonesia Nomor 18 tahun 2012 tentang Panganperubahan atas Undang-Undang No 7 tahun 1996 tentang Pangan. Jakarta.

Undang-Undang Republik Indonesia Nomor 8 Tahun 1999 tentang Perlindungan Konsumen. Jakarta.

Wibowo, Basuki Arif. Kasubsi Prapenuntutan. Kejaksaan Negeri Madiun. Wawancara. 2 September 2010. Madiun.

Widjaja, Gunawan \& Ahmad Yani. 2000. Hukum tentang Perlindungan Konsumen. Gramedika Pustaka Utama. Jakarta.

\section{How to Cite:}

Mulyono, Galih Puji. 2017. Perlindungan Hukum Bagi Konsumen pada Kasus Keamanan Pangan oleh Kejaksaan. Jurnal Cakrawala Hukum. 8 (1): 44-54. 